\title{
Tłumaczenie to za mało - przygotowanie oraz projekcja filmu „Euforia” w polskiej wersji językowej i z audiodeskrypcją (sprawozdanie)
}

DOI: http://dx.doi.org/10.12775/RP.2017.023

27 czerwca 2016 roku w Toruniu odbył się pokaz filmu „Euforia” (Rosja 2006 r., reż. Iwan Wyrypajew). Projekcja stanowiła ukoronowanie prac nad przekładem dialogów z języka rosyjskiego na polski, opisem scen w technice audiodeskrypcji oraz nagraniem nowych ścieżek dźwiękowych filmu.

\section{Audiodeskrypcja, czyli przekład obrazu na słowa}

Barierą, która może uniemożliwiać polskiemu widzowi dostęp do zagranicznej produkcji filmowej, jest brak znajomości języka oryginału lub niski stopień jego znajomości. Odpowiedź na potrzeby tej grupy odbiorców stanowi przekład audiowizualny. Dzięki przetłumaczeniu oryginalnej ścieżki dialogowej i zaprezentowaniu jej w postaci podpisów w języku docelowym, w formie dubbingu (synchronizacji) lub w wersji lektorskiej (voice over) (Tomaszkiewicz 2006: 106-120) produkcja zagraniczna staje się dostępna dla polskiego odbiorcy. Warto zastanowić się nad tym, czy dokonanie transferu językowego jest wystarczającym sposobem na udostępnienie filmu każdemu widzowi? Grupą, dla której przekład to zdecydowanie za mało, są osoby z niepełnosprawnością wzroku. O ile mają one dostęp do ścieżki dźwiękowej dzieła (oryginalnej lub przetłumaczonej), to jego warstwa wizualna pozostaje poza zakresem ich percepcji. Naprzeciw ich potrzebom wychodzi audiodeskrypcja.

Audiodeskrypcja to: „werbalny, dźwiękowy opis obrazu i treści wizualnych zawartych w audycji audiowizualnej, przeznaczony dla osób niepełnosprawnych z powodu dysfunkcji narządu wzroku, umieszczony w audycji lub rozpowszechniany równocześnie $\mathrm{z}$ audycją"1.

1 Przytoczona definicja zawarta jest w Ustawie z dn. 25 marca 2011 r. o zmianie ustawy o radiofonii i telewizji oraz niektórych innych ustaw (zob. art. 4., pkt. 28). Na mocy tego samego dokumentu dostawcy usług medialnych zobowiązani są do udostępniania programów opatrzonych audiodeskrypcją w zakresie co najmniej 10\% kwartalnego czasu emisji. Warto dodać, że wymóg ten, w analogicznym zakresie procentowym, dotyczy także konieczności zapewniania 
Audiodeskrypcja jest techniką opisu mającą na celu przekazanie osobom niewidomym i niedowidzącym informacji na temat wizualnej warstwy filmu ${ }^{2}$. Opisy w audiodeskrypcji relacjonują m.in.: cechy zewnętrzne bohaterów, ich zachowanie oraz wykonywane przez nich czynności, rekwizyty i sprzęty obecne w otoczeniu bohaterów, wygląd miejsc, w których rozgrywa się akcja. Opisy są prezentowane w formie werbalnej dźwiękowej, dzięki czemu ich percepcja zachodzi kanałem słuchowym. Audiodeskrypcja jest dodawana do ścieżki dialogowej filmu w taki sposób, aby zawierała się w przerwach pomiędzy partiami dialogowymi i nie kolidowała $\mathrm{z}$ pozostałymi elementami dźwiękowymi (odgłosami dochodzącymi z otoczenia bohaterów, utworami muzycznymi itp.). Ze względu na ograniczone ramy czasowe opisy skupiają się wokół informacji najistotniejszych, niezbędnych do pełnego zrozumienia akcji filmu. Zadanie audiodeskrypcji polega zatem na udostępnianiu docelowemu odbiorcy tych treści, które - w oryginalnej formie - pozostają dla niego niedostępne. W odniesieniu do potrzeb widzów z uszkodzonym wzorkiem audiodeskrypcja spełnia rolę przekładu. Komunikatem wyjściowym, podlegającym procesowi tłumaczenia, jest w tym przypadku obraz (rozumiany szeroko jako warstwa wizualna filmu lub dowolnego dzieła sztuki opatrywanego opisem), komunikatem docelowym - tekst zaprezentowany w formie ustnej. Odwołując się do klasyfikacji odmian przekładu, zaproponowanej przez Romana Jacobsona, audiodeskrypcję ujmuje się jako rodzaj tłumaczenia intersemiotycznego (Jacobson 2009: 43-45; Chmiel, Mazur 2011: 15).

\section{Projekt „Euforia” - założenia, uczestnicy, przebieg prac}

Projekt „Euforia” został zrealizowany przez członków Koła Naukowego Rosjoznawców skupionych w Sekcji Translatorycznej ПЕРЕВОДКА (Katedra Filologii Słowiańskiej, UMK w Toruniu). Czas realizacji projektu obejmował rok akademicki 2015/2016.

Do założeń projektu należało:

- przetłumaczenie dialogów filmowych z języka rosyjskiego na polski;

- wykonanie audiodeskrypcji do filmu;

udogodnień dla osób z niepełnosprawnością słuchu: napisów dla niesłyszących oraz tłumaczenia na język migowy (zob. art. 18a, ust.1.).

2 Audiodeskrypcja filmowa jest jedną z wielu odmian opisów. Dyscypliny sztuki i formy działalności kulturalnej, w których technika ta znajduje zastosowanie to np.: wystawy, muzea, miejsca stanowiące atrakcję turystyczną, wydarzenia o charakterze widowiskowym czy spektakle teatralne. 
- nagranie nowych ścieżek dźwiękowych: polskojęzycznej wersji dialogowej w formie dubbingu oraz ścieżki audiodeskrypcji;

- projekcja filmu (w polskiej wersji językowej), dostępnego dla osób z niepełnosprawnością wzroku.

Założenia były realizowane $\mathrm{w}$ dwóch grupach. Pracę pierwszej z nich koordynowała opiekun Sekcji Translatorycznej, dr Monika Krajewska. Do zadań tej grupy należało: spisanie oryginalnej ścieżki dialogowej filmu, określenie ram czasowych poszczególnych partii dialogowych (tzw. „czasówki”) oraz przetłumaczenie dialogów z języka rosyjskiego na polski. Drugi zespół, pod kierunkiem Agaty Bernaś, doktorantki z zakresu bibliologii i informatologii UMK (rozprawa doktorska na temat audiodeskrypcji), zajął się wykonaniem opisów do filmu. Etapem poprzedzającym rozpoczęcie prac były warsztaty z tworzenia audiodeskrypcji filmowej adresowane do członków Sekcji ПЕРЕВОДКА, przeprowadzone przez Agatę Bernaś.

Finalną fazę projektu stanowiło nagranie nowych ścieżek dźwiękowych do „Euforii”. Pierwszym z podjętych kroków był wybór lektorów, którzy odczytają dialogi oraz audiodeskrypcję. Tego zadania podjęli się chętni tłumacze i audiodeskryptorzy. Do grona lektorów dołączyły także osoby niebiorące udziału w poprzednich etapach prac. Filmowym postaciom głosu użyczyli studenci i wykładowcy Katedry Filologii Słowiańskiej oraz absolwenci filologii rosyjskiej zaprzyjaźnieni z Sekcją Translatoryczną. Drugim krokiem były warsztaty z emisji głosu i podstaw pracy w studiu nagraniowym, przygotowujące lektorów do etapu studyjnego. Nagrania zostały zrealizowane w Studiu Sferax działającym przy Radiu Sfera UMK.

\section{„Euforia” z polskim dubbingiem i audiodesksrypcją - organizacja projekcji filmu}

Zwieńczeniem kilkumiesięcznej pracy była projekcja filmu „Euforia” w wersji dostępnej dla szerokiego grona widzów - zarówno odbiorców nieznających języka rosyjskiego, jak też osób z uszkodzonym wzrokiem. Wydarzenie zostało poprzedzone odpowiednią promocją. Objęła ona lokalne media, media społecznościowe i środowisko osób z niepełnosprawnością wzroku. Zaproszenia na projekcję przygotowano $\mathrm{w}$ dwóch wersjach: tradycyjnej (tzw. pismo czarnodrukowe) oraz w systemie pisma punktowego Braillea. Projekcja filmu odbyła się 27 czerwca 2016 roku w auli Collegium Humanisticum (Wydział Nauk Historycznych UMK). Wśród zaproszonych gości na widowni zasiedli 
m.in. przedstawiciele Koła Polskiego Związku Niewidomych w Toruniu oraz pracownicy toruńskiego Ośrodka Czytelnictwa Chorych i Niepełnosprawnych. Przed seansem wręczono nagrodę dla zwycięzcy w konkursie ogłoszonym przez Sekcję Translatoryczną ПЕРЕВОДКА. Zadanie konkursowe polegało na przetłumaczeniu treści zaproszenia zapisanego w systemie Braille’a na tradycyjny tekst.

O skali przedsięwzięcia, jakim był projekt „Euforia”, najlepiej świadczy liczba osób zaangażowanych w jego realizację. Warto wymienić tu wszystkich uczestników:

\section{Tłumaczenie}

Dominika Biedulska

Elżbieta Buczyńska

Katarzyna Jóźwiak

Marta Gaszak

Wiktoria Łukasiewicz

Anna Mączyńska

\section{Korekta:}

Monika Krajewska, Marta Gaszak

\section{Audiodeskrypcja}

Agata Bernaś

Elżbieta Buczyńska,

Marta Gaszak

Michał Kaproń

Monika Krajewska

Wiktoria Łukasiewicz

Karolina Zaborowska

Pod kierunkiem:

Agaty Bernaś

Konsultacja skryptu audiodeskrypcji:

Mariusz Kowalski

W dubbingu głosu użyczyli

Bepa - Małgorzata Kudlik

Паша - Andrzej Chrzanowski

Валерий - Łukasz Gemziak 


$\begin{array}{ll}\text { Алёша } & \text { - Mikołaj Tański } \\ \text { Андрюша } & \text { - Kamil Gofron } \\ \text { Галя } & \text { - Marta Gaszak } \\ \text { Григорий } & \text { - Vlad Nowajczyk } \\ \text { Lekarz } & \text { - Vlad Nowajczyk } \\ \text { Ленка } & \text { - Anna Graszek-Tańska } \\ \text { Лидка } & \text { - Ewa Ślusarczyk } \\ \text { Люба } & \text { - Monika Krajewska } \\ \text { Маша } & \text { - Zuzanna Gaszak-Nowajczyk } \\ \text { Мишка } & \text { - Łukasz Majewski } \\ \text { Przyjezdny 1 } & \text { - Eukasz Majewski } \\ \text { Przyjezdny 2 } & \text { - Kamil Gofron } \\ \text { Sąsiad } & \text { - Vlad Nowajczyk } \\ \text { Sąsiadka } & \text { - Irena Matczyńska }\end{array}$

\section{Audiodeskrypcję odczytał}

Michał Kaproń

Napisy odczytała

Agata Bernaś

W przygotowaniu do nagrań pomocy udzieliła

Marta Jenczewska

\section{Nagrania zrealizowano $w$}

Studiu Sferax (Radio Sfera UMK)

\section{Realizacja dźwięku}

Jakub Bryndal

\section{Wsparcie finansowe projektu}

Katedra Filologii Słowiańskiej Uniwersytetu Mikołaja Kopernika

Fundacja Amicus Universitatis Nicolai Copernici

Należy dodać, że $\mathrm{w}$ ramach projektu zaplanowano także drugi pokaz. Odbył się on 24 listopada 2016 roku w Klubie Filmowym „Horyzont” w Gdańsku (Rosyjskie Centrum Nauki i Kultury). Wydarzenie zorganizowano dzięki pomocy p. Kariny Makarewicz (KF „Horyzont”), która współpracuje z Sekcją Translatoryczną ПЕРЕВОДКА i która pomogła w wyborze filmu do projektu. 
Przedsięwzięciem zainteresował się również Świdnicki Ośrodek Kultury. Projekcja „Euforii” zostanie włączona do cyklu „Wieczorów z Kinem Rosyjskim”, prowadzonego przez p. Natalię Nikolską (ŚOK). Wydarzenie planowane jest na jesień 2017 roku.

\section{Literatura}

Chmiel, A., Mazur, I., 2011, „Audiodeskrypcja jako intersemiotyczny przekład audiowizualny - percepcja produktu i ocena jakości", [w:] Przekład jako produkt i kontekst jego obioru, I. Kasperska, A. Żuchelkowska (red.), Poznań, s. 13-30.

Jacobson, R., 2009, „O językoznawczych aspektach przekładu”, przeł. L., Pszczółkowska, [w:] Współczesne teorie przekładu. Antologia, P. Bukowski, M. Heydel (red.), Kraków, s. 41-49.

Ten film jest niezwykły, bo moga go zobaczyć niewidomi, http://ddtorun.pl/ pl/542_student/5333_ten_film_jest_niezwykly_bo_moga_go_zobaczyc_niewidomi.html (dostęp: 21 czerwca 2016 r.).

Tomaszkiewicz, T., 2006, Przekład audiowizualny, Warszawa.

Ustawa $z$ dnia 25 marca 2011 r. o zmianie ustawy o radiofonii i telewizji oraz niektórych innych ustaw, Dz.U. $2011 \mathrm{nr} 85$ poz. 459, http://isap.sejm.gov. pl/DetailsServlet?id=WDU20110850459 (dostęp: 13 listopada 2016 r.).

Agata Bernaś

agatabernas-22@o2.pl

(Uniwersytet Mikołaja Kopernika w Toruniu) 
Joanna Kubaszczyk, Faktura oryginału i przekładu. 0 przekładzie tekstów literackich. Wydawnictwo Naukowe PWN, Warszawa 2016, 272 strony (omówienie książki)

D0I: http://dx.doi.org/10.12775/RP.2017.024

W bogatym zbiorze Wydawnictwa Naukowego PWN ukazała się kolejna, cenna publikacja autorstwa Joanny Kubaszczyk - germanistki, tłumacza i uznanego językoznawcy Instytutu Lingwistyki Stosowanej UAM w Poznaniu, zajmującej się zagadnieniami z dziedziny przekładoznawstwa. W swej książce autorka koncentruje się na teoretycznej i praktycznej stronie przekładu literatury polskiej i niemieckiej, wskazując na liczne problemy związane z prawidłową interpretacją faktury tekstu odgrywającej niebagatelną rolę $\mathrm{w}$ procesie translacji. Podstawę badawczą stanowią fragmenty takich znanych dzieł poetyckich i prozatorskich, jak: Ferdydurke Witolda Gombrowicza, Pan Tadeusz Adama Mickiewicza, wiersze Zbigniewa Herberta i Wisławy Szymborskiej, Dzienniki gwiazdowe Stanisława Lema, Szczurzyca Güntera Grassa czy Pianistka Elfriede Jelinek oraz ich przekłady na język polski i niemiecki.

Joanna Kubaszczyk w usystematyzowany i przejrzysty sposób zaplanowała strukturę publikacji, przedstawiając swe obserwacje w trzech obszernych rozdziałach poświęconych związkowi między warstwą brzmieniową tekstu a jego przekładem oraz roli pisowni i interpunkcji. Jak zatem można zauważyć, przedmiotem rozważań autorki jest „to, co na powierzchni” - warstwa brzmieniowa i sposób zapisu. Kubaszczyk skutecznie udowadnia, że zewnętrzna struktura języka, jego postać graficzna w dziele literackim nie pełni jedynie funkcji językowego ozdobnika oraz nie jest wyłącznie wyrazem kreatywnego działania pisarza. Elementy te odgrywają ponadto istotną rolę przy współtworzeniu inherentnej wymowy dzieła na płaszczyźnie semantycznej. Tym istotniejsze, aby w procesie interpretacji nie ograniczać się do poszukiwań ukrytej metaforyki w warstwie symbolicznej, lecz aby otworzyć się także na to, co widoczne na powierzchni tekstu. W tym celu tłumacz musi podjąć wysiłek, aby odszyfrować funkcję środków językowych zastosowanych przez pisarza oraz dokonać jej transferu do języka docelowego przy pomocy takiego ekwiwalentu, który będzie zrozumiały dla odbiorcy zakorzenionego w określonych realiach kulturowych. Kubaszczyk podkreśla, że bez tego kroku niemożliwy jest wybór odpowiedniej strategii translacyjnej. 
Dla lepszego zobrazowania omawianego problemu autorka prezentuje bardziej i mniej trafne sposoby rozwiązań na przykładzie wybranych dzieł polskiej i niemieckiej literatury, wzbogacając je o inne możliwe bądź bardziej uzasadnione propozycje tłumaczenia. Kubaszczyk uświadamia, ile trudności napotyka tłumacz w swej pracy i dlatego za pośrednictwem swej książki stara się uwrażliwić czytelnika na tytułową fakturę tekstu. Przekonuje, aby nie bagatelizować etapu, na którym dokonujemy diagnozy danej przeszkody $\mathrm{w}$ procesie translacji wynikającej z odmienności systemów kulturowych i językowych oraz własnej niewiedzy na temat funkcji danych środków wyrazu, gdyż od właściwej interpretacji w dużej mierze zależy wybór poprawnego ekwiwalentu. Właśnie $\mathrm{z}$ tego powodu autorka skupia się na stronie lingwistycznej omawianej problematyki - należy kształcić tłumaczy w takim kierunku, aby potrafili w pełni wykorzystać swój warsztat i wrodzony potencjał intuicji językowej, dzięki którym będą w stanie umiejętnie posługiwać się swym głównym narzędziem pracy, jakim jest język oraz rządzące nim reguły w komunikacji wybranych obszarów kulturowych, gdzie to właśnie tłumacz pełni odpowiedzialną rolę pośrednika.

W pierwszym rozdziale dotyczącym warstwy brzmieniowej Kubaszczyk prezentuje swe dywagacje na temat brzmień słownych, rytmu, tempa, podobieństw i różnic brzmieniowych. Ponadto obszernie analizuje przykłady zniekształceń fonetycznych i instrumentacji wypowiedzi przy użyciu takich środków jak stylizacja brzmieniowa, symbolizm dźwiękowy czy rytmiczne uporządkowanie wypowiedzi. Sygnalizuje przy tym, że zachowanie ich w postaci dominanty przekładowej kosztem wierności warstwie semantycznej bardzo często jest jedyną słuszną opcją wybraną przez tłumacza. Zdarza się, że konsekwentne zachowanie formy staje się zadaniem priorytetowym ze względu na szczególny walor artystyczny twórczości danego pisarza, o którym decydują naleciałości dialektyczne, regionalizmy, stylizacja środowiskowa bądź elementy języka archaicznego czy charakterystycznego dla dzieci. Autorka wskazuje, popierając swój wywód licznymi przykładami, jak istotne jest odtworzenie tych komponentów w przekładzie przy pomocy adekwatnych środków językowych i zabiegów stylistycznych funkcjonujących w języku docelowym dla zachowania wartości estetycznej tłumaczonego dzieła. Tłumacz utworów literackich często musi stanąć przed dylematem, czy powinien odstąpić $\mathrm{w}$ danym przypadku od wierności semantycznej na rzecz odzwierciedlenia w przekładzie faktury lub czy bardziej uzasadnioną decyzją będzie skupienie się przede wszystkim na przekazie treści. Z tego powodu autorka stara się wykształcić u tłumacza sięgającego po niniejszą publikację nawyk dokładnej analizy oryginału pod tym właśnie kątem - przed przy- 
stąpieniem do tłumaczenia trzeba dokładnie zbadać powierzchnię tekstu, zdiagnozować intencję autora oraz indywidualne strategie estetyczne zastosowane w dziele. Dlatego oprócz niezbędnego warsztatu lingwistycznego tak ważna jest wiedza i świadomość tłumacza, i to nie tylko w dziedzinie języka, lecz także w zakresie specyfiki zjawisk kulturowych oraz możliwości ich przekazu w języku docelowym.

W drugim rozdziale Joanna Kubaszczyk pochyla się nad problematyką jej zdaniem niesłusznie marginalizowaną w teorii przekładu - pisowni i jej znaczenia w kontekście przekładu. Wyjaśnia, że nie należy lekceważyć tego aspektu, gdyż konstytuuje on wraz z treścią sens utworu osadzony w formie graficznej i akustycznej. Dla poparcia swej tezy poddaje szczegółowej refleksji kwestię ortografii, funkcję błędów pisowni czy grafostylistyki oraz oceny (często niemożliwej do dokonania), czy dany element można rozpatrywać w kategorii błędu, czy jest on może wynikiem świadomego zamysłu artystycznego twórcy. Autorka pokazuje w ten sposób, że grafostylistyka oraz reguły zapisu potrafią przysporzyć tłumaczowi wielu trudności, których w żadnym wypadku nie należy lekceważyć. Świadomość decydującego znaczenia obecności znaku w fakturze tekstu i odpowiednie rozpoznanie takich elementów pozwala jednakże często na znalezienie ekwiwalentów zrozumiałych $\mathrm{w}$ danych realiach kulturowych i językowych.

W ostatnim rozdziale Kubaszczyk poświęca swe rozważania interpunkcji oraz jej funkcji w przekładzie, objaśniając je w odniesieniu do poszczególnych znaków interpunkcyjnych. W szczególności skupia się na przypadkach zaczerpniętych z przekładów wybranych utworów literackich, gdzie tłumacze zdawali się ignorować znaki interpunkcyjne obecne w tekście wyjściowym i nie respektowali ich również w przekładzie. $\mathrm{W}$ ten sposób autorka zamierza unaocznić czytelnikowi, jakie konsekwencje może nieść ze sobą taka nieprecyzyjność dla ogólnego przesłania tłumaczonego dzieła - w zależności od charakteru błędu tłumacz $\mathrm{w}$ ten sposób dokonuje wedle swego uznania zmian w rytmie tekstu, uniemożliwia jego transparentność, a tym samym w obliczu diametralnych zniekształceń - modyfikuje wydźwięk dzieła i zamyka drogę ku właściwej interpretacji.

Główną wymowę publikacji Kubaszczyk można by ująć w następujący sposób: dzieło literackie w całej swej postaci jest wielowymiarowe, a jego sens współtworzy zarówno forma, jak i treść, i taka też powinna być praca tłumacza nad przekładem - wielopłaszczyznowa, nowatorska, kreatywna, niestroniąca od eksperymentów oraz taka, która poszukuje rozwiązań uwzględniających zarówno relewancję faktury tekstu, jak i jego warstwy semantycznej. Trzeba zwrócić uwagę na fakt, że taka harmonia często jest niemożliwa do 
zrealizowania. Nie oznacza to bynajmniej, aby takich prób zaniechać - to umiejętność postrzegania oryginału jako tworu złożonego i polifonicznego oraz dążenie do ujęcia przekładu w koherentnej postaci respektującej w możliwie najbardziej sprawiedliwy sposób wszystkie warstwy tekstu gwarantują już połowę sukcesu tłumacza.

Ogromną zaletą książki Joanny Kubaszczyk jest analiza autentycznych przykładów zaczerpniętych ze znanej szerokiemu gronu odbiorców literatury polskiej i niemieckiej oraz fragmentów przekładów pod kątem trafności wybranych rozwiązań translacyjnych, wzbogaconych o inne możliwe koncepcje i solidną bazę teoretyczną. Autorka zwraca uwagę na silną korelację obu dziedzin nauk filologicznych - językoznawstwa i literaturoznawstwa, koncentrując się na analizie ich harmonijnego współdziałania w obszarze twórczości pisarskiej. Dzięki temu pozycja ta nie jest adresowana wyłącznie do badaczy związanych z tymi dziedzinami i tłumaczy chcących udoskonalić swą wiedzę, lecz do wszystkich zainteresowanych literaturą i teorią przekładu.

Faktura oryginału i przekładu idealnie wpisuje się w kanon naukowych refleksji nad teoretycznym i praktycznym wymiarem zjawiska przekładu. Jednocześnie otwiera nowe perspektywy, proponując oryginalne sposoby podejścia w procesie translacji, gdzie dotąd niedoceniana faktura staje się podmiotem zdolnym do współkonstytuowania sensu.

\author{
Natalia Chodorowska \\ n.chod@doktorant.umk.pl \\ (Uniwersytet Mikołaja Kopernika w Toruniu)
}

